\title{
Familiar Experiences among Continents (Portugal, Africa, and Brazil)
}

\author{
Zeila Demartini \\ Centre for Rural and Urban Studies (CERU), Methodist University of São Paulo, Brazil
}

Copyright $\subset 2017$ by authors, all rights reserved. Authors agree that this article remains permanently open access under the terms of the Creative Commons Attribution License 4.0 International License

\begin{abstract}
Political movements and wars in the Portuguese colonies in Africa in the 1970s were important in determining migration to Sao Paulo - Brazil, especially for those of Portuguese and their descendants who used to live there. In this paper, we seek to understand these new migratory flows and their influence on family experiences using oral histories of immigrants and their families as a complementary along with other sources. The narratives provide insight into the complex dynamics of family during their shifts; we find the conditions for the arrival of Portuguese to African regions, experiences of generations and the immigration to Brazil according to the existing possibilities at that time. With regards to family dynamics, we observed the frequent and unexpected separations in the immigration process and the constitution of families with different "cohabitation" in Portugal, Africa, Brazil - in each displacement, and disruptions of relatives who remain in the previous context or heading into other. The displacements of the African countries towards Sao Paulo in the 1970s contributed in the formation of "intercontinental" and mutant families, formed in each context by different participants. The reports made reference to family absences, the similarities and differences of cohabiting that were a result of living in a long distance. The displacements has not finalized for most families. There is a constant flow among Portugal, Africa and Brazil permeating these flows for economic, political, sentimental reasons, that brings people from different contexts together.
\end{abstract}

Keywords Family Experiences, Lusophone Africa, Portugal, Sao Paulo

\section{Introduction}

Political movements and wars in the Portuguese colonies in Africa in the 1970s were important in determining the Portuguese migration to Sao Paulo, Brazil, and their descendants who used to live there. We seek to understand these new migratory flows and their influence on family experiences using oral histories of immigrants and their families in a complementary way to other sources. The narratives provide insight into the complex dynamics of family in shifts; we try to find out the conditions the Portuguese arrival to the African regions, and the immigration experiences of generations to Brazil according to the existing possibilities at that time.

\section{Generations' Families and Immigration: the Research}

If "to be immigrant" as an expression of Sayad (2000) brings homogeneities given by the process of departure and arrival and by the illusion of "temporariness of the condition" in which they live, we can also affirm that the contexts that are inserted bring differentiating elements. Hence, studying the experiences of Portuguese families settled in the former Portuguese colonies in Africa and then moved to Brazil (Sao Paulo) raises possibilities for researchers to better understand the displacement of populations in the world today and how families view it through the experiences that they have undertaken.

The reflections that are here based on the observations obtained in the research work of exploratory and qualitative nature. As pointed out in other writings (Demartini et al., 2005) data on the movements of some parts of Africa to Brazil in the concerned period is not provided by official offices of Brazil (that claims to be non-existent) and such flows have been still very little studied. Our interest in these flows comes; on the one hand, due to monitoring the arrival of some people from Africa to Sao Paulo, a fact that aroused interest in the problem at the moment that, as a researcher, did not work with the theme of migration; was, however, recorded as an event that came to mark deeply the relations within the family. Later, after studying for many years, Japanese immigration processes and their integration into Sao Paulo's society during the twentieth century (Demartini, 1997), a group with a high profile in the population (currently cover about one million people, in Sao Paulo alone), we have turned to study the Portuguese immigrants, 
perhaps the most "invisible" population group, studying the period of the late twentieth century, when they arrived in large numbers, surpassing the entry of Italian immigrants. This study (Demartini, 2003) was the bridge so that we could propose the study of the most recent period when other characters -also of Portuguese origin- began to arrive to Sao Paulo, but bringing different experiences of previous migratory waves.

The study discusses two large flows which took place in the same period, but with distinct origins: those who came from Portugal, where they have lived and those who came from former Portuguese colonies of Africa, where their families lived. We seek to understand the motivations involved in these migration flows, as well as the trajectories and experiences of individuals and their families in the new context of adoption. In this text, we focus on the second one.

As the availability of quantitative data and its acquisition proved to be unfeasible, the choice of a qualitative approach based on what today is called Oral History, but under the sociological approach, the investigation of issues / problems based on oral sources in a complementary with data from other natures, was imposed as a condition for the study's fulfillment (Lang, Campos and Demartini, 1998). Also, as discussed in other researches (Demartini, 2005), the oral sources are fundamental to understand and enrich the knowledge of African history. Some recent studies (Mateus, 2006) have confirmed its importance.

In our case, the following questions instigated us: who were these "new" characters who arrived in São Paulo? Was the last Migration similar to the previous ones, in which many Portuguese came seeking a better life, the "árvore das patacas," as they used to say? Our previous interviews and information have showed that it was not. The immigrants were very different from families with different trajectories. Thus, it is so important to know and understand them in a detailed comprehensive way.

The difficulties presented themselves; however, they were not few - not mentioning the little amount of literature and information available. Hence, it was necessary to find people and talk to them - where? Were they related to families who had come to Sao Paulo long before? The search has been conducted in several ways starting from consulting the institutions related to Portuguese immigrants, through collecting information from people and searching the web.

Therefore, the interviewees are a group of immigrants came from Africa to Brazil at the same time, but they did not form a social group that maintained relations with each other, before or after arrival. Some of them have been prominent people, known for their role in Sao Paulo; others have also become "invisible" not been generally recognized by local population as people who came from Africa, but simply as Portuguese (given the origin, language and white color).

The interviews have not been identical either although the research proposal aims to obtain and summarize life histories of each respondent (Demartini et al., 2005), in order to understand its history and its family group, from Portugal. While some said more generic issues, others gave more details about different times and different generations of the families.

\section{Shifts to Africa, the Family has Experienced in the Former Portuguese Colonies and Coming to Brazil}

Overall, the number of interviews attained and the contact with the interviewees and their families allows us to have a better understanding of the different dimensions of family trajectories as they travel among the continents of Europe, Africa and America. It is also possible to observe that the displacement of families from Portugal to the colonies in Africa and from these regions to Brazil are not represented as processes that are similar - while going to Africa was generally regarded as natural - as the offset within in the same country, in what was considered the "Portuguese nation expanded," the displacement to Brazil was felt and represented by individuals as an "expulsion", a forced departure of a territory that was considered theirs.

An analysis of the trajectories of the families of respondents shows that there were many periods and reasons for the displacement of families to the Portuguese domains in Africa. On the other hand, there was a common motivation (the strong pressure and threats of revolutionary movements) for them to leave the ex-colonies - which occurred at the same time - the year 1975 .

It is interesting to take into consideration how relation and reconstruction of the families happened and were represented during these two great streams of families of Portuguese origin: 1) from Portugal to the African colonies and 2) from the former colonies to Brazil.

The interviews point out varied reasons and periods in which they or their families came to the African territories of Angola and Mozambique. Some families arrived four generations ago. At that time, there were relatively few settlers, who are often located in specific regions, not throughout the territory of Angola and Mozambique. During that period, according to some authors, even the cohabitance between the settlers and several groups who inhabited these regions appeared to be more "peaceful" (Cosme, 1978). Some talked about the arrival of their maternal and/or paternal great-grandparents to these African lands, so long before the colonization became more focused and strong in the 1950s and 1960s.

The study figures out that several families came to escape from difficult living conditions in Portugal, which leaded men , mainly, to look for a better employment and salary in the African lands (some regions of Africa were also viewed as "the making America" of Portuguese immigrants who came to Brazil). However, there were other reasons behind the Portuguese leaving for Africa, and one of which was looking for better social substitution (in order to solve families and love quarrels). There were also those who were 
connected to great private enterprises or to the Portuguese State. In some cases, families who left Portugal did not remain in the same place of arrival, but moved among the Portuguese colonies in Africa.

Other interviewees reported the arrival of their families, in the period when Portugal encouraged the departure of Portuguese settlers to "their" lands in Africa, as a part of a State project of political and economic occupation of their colonial territories (Pimenta, 2005; Graça, 2005; Fernando, 2005).

Some cases may be taken to exemplify such situations showing how during these processes of displacement in Africa and then to Brazil generated separations and new encounters that led to forming families with different compositions and cohabitation in each context. Here, we focus on families who went to Angola and from there to Sao Paulo.

\subsection{The case of Families Who Came to Angola in the First Half of the Twentieth Century}

Some interviewees resemble the families' paths, and how their relatives inserted in the African context and then achieve their projects of social mobility.

The case of family E. 1 is important for the reflections on the family trajectories: it is a family that had come to Angola for several generations. As reported by the interviewee:

I am African because I am a daughter of Africans. My great-grandmothers were in Africa. My grandmothers were children and my grandfathers were already adults when they went. So, now my parents are African, I am an African and if I had not come here, my children probably would be African. I started studying in school. I remember that I went to a path that I can not say well why, never questioned, even because the family members had a more rigid education, then what is this idea of questioning a father the reason why for many things. "Yes, because the best is what I think." So I'm from this education and I remember that I studied in a private school in first grade. In second grade, I went to a public school. In third grade, I returned to a private school (...); schools were mixed. In the fourth grade I went to Europe; I went to Portugal to an internal school because I became at the age of learning manners. No, it was not even subjects, I think this is like this, there would be a school, near Serra da Estrela, where all my family had studied, so where there were people... It was a tradition, my family thought that an internal school would make me more rigidity that was not Sufficient in the house and among friends. I liked to have fun. I really liked people; so, I played ball in the street, and climbed trees. For my family, doing that was not appropriate, or it was not for a girl. I had a brother. He was calmer and, he is a man, so all right. However, as a girl, I had to have something more strict and regulated. (...) He stayed, and I had gone to the internal school for three years, spending vacations and everything and then I went back there and then went to the public education...

The important thing in this story is that the standard of education continued to be what was expected in Portugal. The distance between Angola and Portugal was vast and still did not prevent parents from sending their children to study there. The goal was not to their professionalism or further education, but rigid education from Portuguese's boarding school, which in Africa it seemed not available. The interviewee talked how her behavior was not concurred to what was expected of a girl. The reports of sanctions show how the pattern of Portuguese family education had persisted even the family had arrived to Angola for many generations.

The respondent and her family were fully inserted in the Angolan context. Although they supported the independence movements in Angola, they were forced to leave the country in 1975, because they were "white", fled to Portugal, where they were met with aggression by local people. They decided, therefore, to come right after to Brazil, where they rebuilt their lives.

It is interesting to note that in spite of all the coexistence of the standards of Portuguese families held by E.1 family, they felt rejected when they sought a shelter in Portugal after leaving Africa:

(...) We were not accepted by the Portuguese, we were "returnee", and I could not understand what this returnee means! I had never left there, how was I a returnee? I was a refugee, I didn't return! Perhaps some Portuguese who lived in Angola were returnees, but I was not, right? I was a stateless person. We did not know. We would not have a job in Portugal, or a place to stay. (...) I arrived in Portugal and I was despised in the sense in my reception when I landed at Lisbon airport, there was a manifestation of communists, PC, Portuguese Communist Party, some hooligans, I knew from their way of shouting: "They stole the blacks, now, they are going to steal the white! Go away to your land!" I had not robbed anybody, and I was not a returnee. (...) it was a shock, a total disappointment. We were in a situation that could not be corresponded, I said, "Guys, what is this? What is happening?"

The family origins were not enough to retain them in Portugal. The interviewee explained how, in Sao Paulo, there was a support network to provide jobs for those who came from Africa, which was soon realized, not mentioning the presence of family in this new context.

Also interviewee E.2 says that his family had come to Africa for several decades:

(...) My father and my mother are already Angolans. My grandparents, both paternal and maternal, were Portuguese from Portugal and they were born there in Europe. (...) What we know about their living to there is as the following: . Angola had to be colonized by Portugal, then what happened? Some people would be chosen to go there, right, others came to a certain point to go there, to go to Angola. You would go there only 
when the government decided to provide services or even to live there, or if you had someone had been already there, for example, someone that would invite and take responsibility for you there in Angola. (...) My family, most of all was in Angola. In Portugal, we basically had uncles and aunts, but still, you know, well, like, second degree. Once in a while, they came to visit; and when we went there, they often insisted that we had to stay at their house. I had some uncles and aunts in Lisbon and others stayed in the villages.

The departure of the grandparents to Angola; a land that was considered Portuguese, allowed that the subsequent generations to live a good life with good jobs which allow them (in its turns) to keep having frequent contacts with Portugal:

(...) My father worked there in the Aviation Company of Angola which was called at the beginning DTA "Direção Transportes Aéreos ", and it was belonged to the government. In Angola, all people who served the government they have the right to get -I don't know if it was- five or six months paid vacation every four years... enjoy Portugal, isn't it? (...) When my father used to get his vacation that the people called license, we would go there and he would take the whole family either by plane or by boat. At the beginning, we used to go by boat and then by plane.

What is interesting about the family E.2 is that when his grandparents went to Angola, a sister of the grandmother chose another destination, and came to Brazil. The political situation and forced exit from Africa allowed the reunion of the sisters, half century later:

(...) I'm Angolan, and I came to Brazil in May 1975 because of the war that was there and I came here from Angola, that's me, my father, my sister, the whole family came. Why did we decide to come here to Brazil? We decided to come to Brazil as we had come on vacation to here earlier and we liked it. My father went to visit the VASP workshops at the time, they promised to give him a job and everything. The situation there was getting bad, too much war, a lot of fighting and civil war started, so we decided to come to Brazil. The contact we had was this: there was an aunt, who was the sister of my grandmother. She was, in this case, my aunt. She came to Brazil and my grandmother went to Angola, huh. There was a movement on immigration, the departure of the Portuguese to various parts of the world. Many people came to Brazil. In the case of my aunt, she came to Brazil, right. It was fifty years since the sisters didn't see each other, you know, so we came because of her, right?

At the same time, they were separated from the other side of the family; the father's relatives:

(...) We are one of the first of our family to come, and then the rest of the family said: "No, we'll stay a little longer, let's see how it looks, as it is ...", then we all came to the conclusion that really had no condition. And what happened? Most relatives from my mother's side, as we were already here, just came to Brazil. Now, my father's relatives, they all went to Portugal.

The respondent also mentioned that the relatives who have remained in Angola - they have a large shoe factory, and kept going back and forth from Angola to Portugal.

All who came to Sao Paulo were living in the house of the aunt for a long time. Reports indicate that, despite the fifty years of separation, the family gave full support to several couples who came from Angola:

(...) When everybody came to Brazil, they lived in the house of my aunt till we reached a point that people in the house can't stand each other anymore, and when everyone began to settle, we said we would have our lives and leave them alone, they had welcomed us, and there was a start of some squabbles, some things that are normal within a family. That was when we start our life. Then, we went to live in this house, a kind of a shared house, everybody lived there and then people started working. Each had stabilized in employment, all had their savings and each rented their homes. We were living in Brooklyn, near Morumbi Shopping, my other uncles were living in a street near Nove de Julho Avenue, others who had also moved near Morumbi Shopping, and others were living, three streets up, they found a good house there and ended up living there. At first, everyone rented it and then gradually, everyone was buying the houses. Finally, who was just a little broke to buy the house, was my father, because his family was there in Portugal, in deep, deep down. My father, I think he wanted to return to Portugal. They spoke several times to return to Portugal, but we didn't return back to Portugal, why? Because we had enjoyed here in Brazil and all my mother's family was here ...

Despite of the relatives in Portugal, the interviewee had not gone to visit them, nor the rest of his family - only the father, during his life, because of his retirement.

\subsection{The Case of Families Who Went in Post-world War II, most Focused Period of Colonization by the Portuguese State}

The interviewee E. 3 tells how her family sought to Africa after the Second World War as a way to improve their lives. Angola was considered by then as a part of the Portuguese nation. The trip was, therefore, the result of a family project, which involved the arrival to Angola; first the father and then the mother and the child - the respondent was born soon after the arrival of the family:

(...) Parents are from northern Portugal, near Porto, a city called Edvaldo Câmara. An uncle of mine had been in the army, the army in Angola for forty years, end the war after the war there. So, he knew Angola, and when he returned to Portugal, Portugal was not in a good situation in the postwar period. Most Portuguese, 
young at that time, became immigrant, because the question was "how to survive". He inspired my father to go to Africa. Then, he came to Brazil and my father went to Angola. First, I was raised in Portugal and I was born in Angola. My mother went there when she got pregnant and then, after a few months, I was born. They had relatives, people from the same village in Portugal who were there. At that time, there was a big wave of Portuguese immigration although it was prohibited. The government had put large barriers to people to not emigrate. But they made all effort to leave the country (...) Portugal did not enter the War, but it was worse than those who entered the war, so that the people decided to risk everything.

Somehow, the family settled well, economically and socially, in the land of Angola. At the independence in 1975, the children there had arrived at the university level. The family had never thought of leaving Angola, to live elsewhere.

Pressures were experienced during the revolutionary process, forcing these families to new destinations. Yet, there was no unanimity of views and resistance, especially from younger family members, who had grown up in Angola. As reported by the respondent:

(...) And Angola was a new country, everything was to be built. People were not worried about life. All what people wanted is to take care of their lives and clear land doing whatever was necessary to do. Then, I saw, I never saw myself, I don't remember me thinking to migrate, so I resisted until the last minute. When I was in Luanda, the capital, with my older brother in 1975, we began studying the Civil War, so we spent a week with no contact with the family, who was in Luanda so that they began to be concerned about this situation. What would happen, what would not happen? And my father sent a letter, which eventually arrived in the house where I lived at that time. In the letter, my father asked us to get back home to discuss what we would do. By chance, the time was close to June and July. June and July holiday, so we went back. However, the country was already in a civil war. One day, we were discussing what they would do. My brother and I were against the discussion and we wanted to stay.

To keep the family cohesive, not only the father, mother and children came, but also the future wife of the brother of the respondent, and even her friend whose parents had gone to Portugal:

(...) We all came together. Father, mother, brothers. Everyone. We are four. There was also my future brother in law, he was my sister's boyfriend back then; today, he is my brother in law. There was also a friend who is in Portugal nowadays. At that time, his parents were no longer in Angola, he decided to come with us to Brazil. And he stayed here for several years, then finally returned to Portugal.
The trajectory of the family E. 3 demonstrates us how the components of the family may, during the migratory process, trigger relatives who were somewhat away to help resolve the problems of forced exile. In this case, the family resorted to the respondent's uncle, who lived in Santos, a port city near São Paulo:

(...) We arrived with $\$ 180$ in the pocket of each of us. Imagine what would you think about in the 70 s at the end of the economic miracle. It was not that strength that Brazil used to have, and we arrived. We had ... there was an uncle of mine here, my father's brother, who lived in Santos, who gave the initial push for us to start, then, we started working. I started working as a waiter at his bar there at the Port of Santos, on Rodrigues Alves Avenue, and looking for what I could do, within somehow six months/one year, I started to see outputs. It gave him strength. That's what made us manage that initial phase. Soon after, my father asked for a loan to the brother and another cousin here from Sao Paulo to start a business there in Santos. He started to set up a business there, a bar, a little bar, right? He started (...) to selling. And with that we were paying for our colleges as none of us could get in public school.

There is, however, that the trajectory of the family group did not stabilize with the coming to Brazil - the parents, a brother with his wife, a sister, returned to in the 1990s. The respondent, who has been married in Brazil to a daughter of Portuguese who came to Brazil after the war and has lived with her family in a town close to Sao Paulo (wife, daughters and mother of his sister), refused to return to Portugal) in a different family arrangement.

As can be seen, the family arrangements were changing in every continent. The interviewee summed up the current situation: "Today the family is divided."

The trajectory of the family E. 4 shows how family ties were important in the choice of destination of migration:

(...) Life in Europe after the war, after 1945, was very difficult. Even Portugal, which did not enter the war, suffered post-war. Marshall Plan was applied more to the countries directly involved in the war and losing than actually to countries that did not participate. Then, Portugal and Spain spent many difficult moments, and I believe my parents seeking for a better future emigrate to Angola, as they could have done it here in Brazil. This emigration to Angola took place when my father had a brother already in Angola in military service. At the time, the Portuguese government forced a document entitled "Letter of Call", ie, a document that the person called a relative or friend would be responsible of them for a certain number of years. Then my uncle, my father's brother, sent this "Letter of Call" that enabled my parents' departure to Angola.

Also in this case, the family has established itself well in the economic activities that were dedicated.

(...) An area where there was everything to do, practically, and I think that any immigrant who leaves 
their lands and try to be successful, especially, when they emigrate with their own willing,. I think it was this tone that my parents repeated ... and I was always very good and ... Always liked the life I did there in Angola.

The respondent continued living with his family in Portugal even after they moved to Angola, after some time, returned to Africa.

(...) I stayed many years in Portugal, because my grandmother was alone in Portugal and my parents thought I would be a good company for her, so I spent seven of my eleven years in Portugal. I was very young, I remember well ... I liked Portugal, as well ... I was very good school. At the time, my parents had, fortunately, a financial situation that allowed them to send me to a good private school (...) So those five years, I lived in Portugal, were very remarkable year for me because I had ... so ... opportunity to live with another civilization, mainly because European civilization was different from "Luso-African" civilization (...) But my grandmother got sick and my parents called her to stay with them. We went to Angola together when I was eleven years old.

However, his relations with Portugal remained strong, as he returned again to Lisbon to study in the University when he finished high school at the age of seventeen. The return from Luanda was motivated by her sister's travel to Switzerland to study, especially, after some members of the family in Portugal wrote to his father saying that at Lisbon he "would stay very comfortable.", again, the relatives accompanying the family experiences.

Like the others, the departure of Angola was due to the worsening political situation. According to the interviewee: "Luanda lived in the battlefield," "the period from March 1975 to October 1975 was actually a hell in Luanda". Portugal was the first destination, accompanying also the mother, who was very ill. After six months, however, the choice of Brazil came: “(...) my wife became pregnant with their first child and I said - 'We need to work', and then, we came to Brazil."

In this case, he had the support of friends and networks of the Brazilian government which allowed him to quickly enter the labor market in the state of Sao Paulo, the woman came a month later, and his son was born in the new context.

The children went after abroad, one in the United States, the other in Portugal, to study and work. The respondent and his wife currently live in the metropolitan area of Sao Paulo.

\section{Some Final Observations}

From the point of view of academic production on migratory processes, the analysis of migratory flows of families from the former Portuguese colonies from Africa to Brazil in the 1970s during the independence processes is important for the understanding of forced displacements of families And their implications for living in new contexts.
This issue has become increasingly important in the present day, as the number of families that have been unstructured during the forced migration process has increased. Issues related to this issue are still little discussed in migration studies, especially in recipient countries. In Brazil, migration studies dealing with these flows are almost non-existent.

From the standpoint of the analysis of the family field, it was possible to observe, in the research carried out, that the forced displacements resulted in frequent and unexpected separations in the immigrant process. In addition, they also resulted in the constitution of families with different "cohabitation" in Portugal, Africa, and Brazil. In each detachment, there were departures from relatives who have remained in the previous context or have been directed to others (without taking into account that, in Brazil, are returning or going to Portugal).

In times of globalization, the analysis of this dimension (family) points out that, in addition to the displacement of hand labor, the frequent shifts, which occurred as a result of the independence movements of the African countries, towards Brazil made the families involve in the "intercontinental" and mutant constitutions formed in each context by different participants (grandparents / parents / children) (parents and children) (alone) and so on. There is almost a tone of "normality" in the stories of immigrants to references to family absences, the similarities and differences of living in long distance.

This study confirms the theoretical contribution of Bourdieu (1993) regarding family studies. The family, in situations of risk, acts not only as a field, but as a body as well. We resume here a few observations of this study carried out among different groups in the state of Sao Paulo assessing the family as a mediator between individual and society:

Bourdieu declared that the family tends to function as a field that would not have a specific capital, but would stream the volume of capital owned by its different members. The data analyzed by us led us to believe that the family could actually be seen as a field and would have even a specific capital, not excluding the sum of capital otherwise possessed by the various members of the family. The family would have a specific capital linked to warmth and emotion: it is the sense of belonging to a group, identified as a family group, of the differentiation with respect to other family groups.

The family as a field is imposed along the research as a tool for explaining the mediating role that social group plays in the struggle at the heart of the wider society and in other diverse fields in order to survival materially (as in the case the settlers) or (as in the case of immigrants). It is to maintain a lifestyle (as in the case of some traditional Brazilian families), while others, of popular origin, seek to ascend socially.

Moreover, the notion of family as a body represent-as represented in our society, was often used when the conflicts within this field could become shredders of that body. In these cases, a well-defined project common to the family group has often made it possible to create clearer and more 
effective group strategies that are capable of maintaining the family as a cohesive body. The cohesion of the family group is designed as a body through some mechanisms: solidarity, cooperation and reciprocity mechanisms that overlap each other and exploited via bonding to constitute the logic that preside over the field of family and that would determine the cohesion of the family group (Lang et al., 1997: 115).

There is also a perverse consequence that accompanies the families that were surveyed: this is the incompleteness of the migration process: shifts occurred in the 1970s, related to political movements, did not end for most families contacted and interviewed. In all most all of the interviews, it has been quoted that there is a return to Portugal in each whether of those who came from there or those who previously were a residence in African countries, and more recently decided to move to the ancient metropolis. Rarely are there indications of the return of families who came from Africa to the continent. We can perceive, mainly through the interviews. There is a movement of constant/continuous flow (although not definitive or clearly resolved) between Portugal, PALOP countries (Angola and Mozambique) and Brazil. Permeating these flows is usually for economic, political, and sentimental reasons, which have approached / estranged people from different contexts and brought them closer to each other.

The study also allows us to think about the colonization processes undertaken by developed nations in other regions of the world and how they can affect the families that participate in these colonization ventures, when conflicts are established with the local populations, implying rapid exits, independent of their projects of life.

These are questions that deserve to be deepened.

\section{REFERENCES}

[1] P. Bourdieu. À propôs de la famille comme catégorie réalisée. Paris: Actes de la Recherche en Sciences Sociales, (100), 32-36, 1993.

[2] L. Cosme. Cultura e Revolução em Angola. Porto: Afrontamento, 1978.
[3] Z. B. F. Demartini. Migrações e relatos orais: as potencialidades das entrevistas com gerações sucessivas. In M. B. Rocha-Trindade \& M. C. S. S. Campos (Org.). Olhares lusos e brasileiros. São Paulo: Usina do Livro, (pp. 157-178), 2003.

[4] Z. B. F. Demartini. Pesquisa histórico-sociológica, relatos orais e imigração. In Z. B. F. Demartini \& O. Truzzi (Org.). Estudos migratórios: perspectivas metodológicas. São Paulo: EduFSCar, (pp. 87-113), 2005.

[5] Z. B. F. Demartini. Viagens vividas, viagens sonhadas: os japoneses em São Paulo na primeira metade deste século. In A. B. S. G. Lang et al. (Org.). Família em São Paulo: vivências na diferença. São Paulo: Humanitas/CERU. (Coleção Textos, série 2, n. 7), 1997.

[6] Z. B. F. Demartini, D. O. Cunha, E. Doppenschmitt. Desafios da pesquisa com fluxos migratórios recentes: portugueses e luso-africanos em São Paulo. Cadernos CERU, série 2, (2), 41-54, 2005.

[7] Z. B. F. Demartini, al. Reflexões. In Família em São Paulo: vivências na diferença. São Paulo: Humanitas/CERU, (pp. 109-126). (Coleção Textos, série 2, n. 7), 1997.

[8] E. Fernando. O último adeus português. Portugal: Oficina do Livro, 2005.

[9] P. B. Graça. A construção da nação em África. Coimbra: Almedina, 2005.

[10] A. B. S. G. Lang, al. (Org.). Família em São Paulo: vivências na diferença. São Paulo: Humanitas/CERU, (pp. 77-95). (Coleção Textos, série 2, n. 7), 1997.

[11] A. B. S. G. Lang, M. C. S. S. Campos, Z. B. F. Demartini. (1998). História oral e pesquisa sociológica: a experiência do CERU. São Paulo: Humanitas/CERU, 1998.

[12] D. C. Matheus. Memórias do colonialismo e da guerra. Porto: ASA. (Coleção Arquivos Históricos), 2006.

[13] M. F. T. Pimenta. Brancos de Angola: autonomismo e nacionalismo (1900-1961). Coimbra: Minerva Coimbra. (Coleção Minerva - História, 24), 2005.

[14] A. Sayad. O retorno: elemento constitutivo da condição do imigrante. Travessia - Revista do Migrante, 13(n. especial), 2009. 